УДК 159.99

doi: 10.32620/gch.2019.4.14

Научитель О. Д., Гулий Ю. І., Садіков Г. М.

\title{
ПСИХОЛОГІЧНА СТРУКТУРА ПРОФЕСІЙНОЇ «Я-КОНЦЕПЦӤ» ВІЙСЬКОВОСЛУЖБОВЦІВ ІЗ РІЗНИМ ТИПОМ ПРОФЕСІЙНОЇ ІДЕНТИЧНОСТІ
}

У статті розглянуто професійну «Я-концепцію» військовослужбовиів, характер взаємозв'язків ї̈ компонентів: когнітивного, поведінкового й емочійного. Ураховувався тип професійної ідентичності особистості.

Ключові слова: професійна «Я-концепція», професійна ідентичність, тип особистості.

The article deals with the professional «I-concept» of military personnel, the nature of the interconnections of its components: cognitive, behavioral and emotional. The type of professional identity of the personality was taken into account.

Keywords: professional self-concept, professional identity, personality type.

Постановка проблеми. Початок XXI ст. актуалізував питання щодо проблеми професійної «Я-концепції» як основи для формування ефективного спеціаліста.

Слід мати на увазі, що структура складових професійної «Я-концепції» аналогічна структурі загальної «Я-концепції» й складається 3 трьох компонентів: когнітивної складової, яка розкриває уявлення про професійно-важливі якості особистості; емоційної - професійної самооцінки; і поведінкової складової, яка відображає уявлення особистості про самоефективність.

Широке коло питань, що стосуються професійної «Я-концепції» військовослужбовців, знайшло своє відображення в роботах С.Т. Джанер'ян, А.М. Рікель, Л.Б. Шнейдер та ін. [1-6].

У контексті цієї проблематики найбільш розробленими $є$ питання щодо професійної «Я-концепції» як особливості професійної самосвідомості військовослужбовців, самооцінки військовослужбовців із девіантною поведінкою, розвитку «Я-образу» військовослужбовців за призовом, професійного становлення молодших командирів військової служби за контрактом і питання їхнього самовизначення, психологічного супроводу.

При цьому недостатньо висвітленими залишаються питання, як тип професійної ідентичності особистості накладає відбиток на структурні елементи професійної «Яконцепції» військовослужбовця; яким $\epsilon$ характер взаємозв'язку між цими структурними компонентами.

Аналіз проблеми. Існують різні концептуальні підходи до розуміння й власне поняття «професійна “Я-концепція"», і іiі структурних елементів. Акцент у цьому може ставитися або на діяльнісному аспекті професійної ідентичності, або на створенні структури й виявленні закономірностей процесів формування професійної 
«Я-концепції», іiі взаємозв’язку з професійною ідентичністю.

Професійна «Я-концепція» постає важливим компонентом у структурі професійної ідентичності, бо в ній існують операціонально-діяльнісний i особистісний аспекти [4]. Спочатку формується когнітивна складова, визначена уявленнями про професійно важливі якості фахівця, потім - емоційна складова. Процес ідентифікації зі своєю професією неможливий без вищеперелічених компонентів професійної «Я-концепції». На підставі формування «Я-концепції» формується професійна ідентичність.

Професійна «Я-концепція» військовослужбовців досі не вивчалася як цілісність, оскільки для підготовки фахівця більш важлива когнітивна складова, що містить ті професійно важливі якості, які є необхідними й достатніми для створення адекватної професійної «Я-концепції» й відповідно професійної ідентичності. Тому основний акцент дослідники робилия на створенні моделі висококваліфікованого професіоналавійськовослужбовця.

Під професійними якостями військовослужбовця прийнято розуміти сукупність бойових, морально-психологічних, духовно-культурних, фізичних, технічних здібностей, знань, навичок і умінь, дії яких застосовуються особистістю для реалізації обов’язків і функцій у процесі військової служби.

Для створення цілісного уявлення про професійну «Я-концепцію» військовослужбовця та формування гармонійного фахівця необхідно доповнити теоретичні знання про їі емоційну й поведінкову складові, бо саме вони на сьогодні $€$ найменш вивченими [3].

Професійна «Я-концепція» є первинною щодо професійної ідентичності. Обидва ці конструкти взаємопов'язані. Дотепер у психологічній літературі не повною мірою розв'язані питання, наскільки тип професійної ідентичності військовослужбовця позначається на тому, яким професійним орієнтаціям, яким складовим когнітивного компонента професійної «Я-концепції» віддається перевага; як це позначається на адекватному оцінюванні ефективності своїх дій і здібності реагування в складних умовах (поведінковий компонент) та адекватному розумінні й емоційному сприйнятті цінності своєї особистості (емоційний компонент); яким є характер зв’язку між цими структурними елементами.

Мета дослідження. Виявити особливості структури професійної «Я-концепції» військовослужбовців відповідно до типу їхньої професійної ідентичності (ТПІ).

Методи дослідження. Метод тестування (методика Л.Б. Шнейдер «МІПІ», методика Е. Шейна «Якорі кар'єри», методика Шварцера-Срусалема-Ромека «Шкала самоефективності», тест «Самооцінка»).

Опис вибірки. У дослідженні взяли участь 100 військовослужбовців. Усі опитані чоловіки у віці 18-23 років. За основу розподілу на групи був узятий ТПІ. У першу групу ввійшли військовослужбовці 3 передчасним ТПI. Друга група військовослужбовці з ТПІ «мораторій». Третя група - військовослужбовці з дифузним ТПI. Четверта група - військовослужбовці з ТПІ «псевдоідентичність».

Результати дослідження. Після порівняння середньогрупових показників тестування груп досліджуваних ( 
Когнітивний компонент «Я-концепції» дозволив виявити таке. $€$ військовослужбовці, які мають різні професійні орієнтації: професійна компетентність, менеджмент, автономія, стабільність роботи, стабільність місця проживання, служіння, виклик, інтеграція стилів життя, підприємство. В усіх чотирьох групах на кожну з цих професійних орієнтацій доводиться не більш однієї третини опитаних. Такий розподіл дає підставу констатувати, що не має однозначного домінування однієї професійної орієнтації щодо інших.

Подальше уточнення дозволило встановити, що військовослужбовці 3 передчасним ТПІ частіше, ніж їхні однолітки 3 професійною ідентичністю «псевдоідентичність», виділяють для себе важливішою автономію $(\varphi=1,72$ за $\mathrm{p} \leq 0,05)$. Військовослужбовці з ТПІ «мораторій» більш орієнтовані на менеджмент $(\varphi=1,74$ за $\mathrm{p} \leq 0,05)$, ніж їхні колеги 3 ТПІ «псевдоідентичність». Опитані 3 дифузним ТПІ особистості - на інтеграцію стилів життя $(\varphi=1,64$ за $\mathrm{p} \leq 0,05)$ порівняно 3 ТПІ «мораторій» та стабільність роботи $(\varphi=1,65$ за $\mathrm{p} \leq 0,05)$ порівняно 3 ТПІ «псевдоідентичність».

Узагальнення вищенаведеного дозволяє констатувати, що в когнітивному компоненті, незалежно від ТПІ, військовослужбовці серед усіх можливих кар'єрних орієнтацій роблять акцент на стабільності роботи й місця проживання, для них важливим є відчуття власної безпеки як у професійній діяльності, так і в особистому просторі.

Разом 3 тим є деякі відмінності. Так, серед військовослужбовців із ТПI «дифузний» і «псевдоідентичність» не має зовсім тих, кому притаманна професійна орієнтація, яка б стимулювала їх у прагненні до кар'єрного зростання (менеджмент); для військовослужбовців із ТПІ «псевдоідентичність» більш важливою $\epsilon$ самостійність у роботі та своїх діях (автономія) порівняно 3 передчасним ТПІ. У військовослужбовців із ТПІ «мораторій» найбільш характерними є бажання бути керівником (ніж для їхніх колег із ТПІ «псевдоідентичність»); пошук відповідності своїм особистим цінностям і своїй роботі (ніж для опитаних із дифузним ТПІ). Для військовослужбовців із дифузним ТПІ серед професійних орієнтацій найбільш важливим $є$ бажання стабільності й безпеки в роботі порівняно 3 ТПI «псевдоідентичність».

Вивчення того, як військовослужбовці оцінюють свою самоефективність (як складову поведінкового компонента «Я-концепції»), дозволило встановити таке. Серед військовослужбовців із ТПІ «мораторій» 75\% опитаних адекватно оцінюють ефективність своїх дій, здібності реагувати в складних умовах, і навпаки, їхні колеги 3 ТПІ «передчасний» (44\%), «псевдоідентичність» (50\%) і «дифузний» $(45 \%)$ схильні недооцінювати ефективність своїх дій, занижувати свої здібності в реагуванні в складних умовах.

Уточнення характеру зв'язку поведінкового й когнітивного компонентів професійної «Я-концепції» військовослужбовців виявило певні відмінності.

ТПІ «передчасний». Зворотній взаємозв'язок прагнення самовираження $(0,64) \mathrm{i}$ допомоги суспільству в умовах конкурентної боротьби $(0,56)$ із прагненням посісти керівну посаду $(-0.74)$, де він буде відчувати ефективність своїх дій $(-0,55)$. 
Поведінкова складова «Я-концепції» й професійна орієнтація, спрямована на кар’єрне зростання, стає перешкодою на шляху професійних орієнтацій бажання самовираження й подолання конкурентної боротьби в суспільстві. Аналогічним був i взаємозв'язок показника поведінкового компонента самоефективність $(0,56)$ i показника когнітивного компонента інтеграція стилів життя $(-0,69)$, тобто усвідомлення ефективності своїх дій заважає бажанню поєднати особисті цінності 3 робочими.

ТПІ «мораторій». Зворотній взаємозв'язок показників когнітивного компонента стабільність місця проживання $(0,65)$, виклик $(-0,66)$ і служіння $(-0,62)$ і показника поведінкового компонента самоефективність $(0,58)$. Існує конфліктна сутність увідомлення безпеки професійної діяльності й ефективності своїх дій і прагнення допомагати людям в умовах міжособистісної конкуренції.

ТПІ «дифузний». Зворотній взаємозв'язок показників когнітивного компонента стабільність роботи $(0,74)$, менеджмент $(-0,62)$ і поведінкового компонента самоефективність $(0,64)$. Прагнення обійняти керівну посаду не збігається 3 прагненням до стабільної роботи, де є можливість відчувати ефективність своїх дій, тобто чітко проявляються як гармонія, так і дисгармонія між різними професійними орієнтаціями як складовими когнітивного компонента професійної «Я-концепції» та елементом її поведінкового компонента.

ТПІ «псевдоідентичність». Зворотній взаємозв’язок показників професійної «Яконцепції»: поведінкового компонента самоефективність $(0,54)$ та когнітивного компонента: професійна компетентність $(0,79)$, автономія $(0,68)$, виклик $(-0,68)$, служіння $(-0,59)$ і стабільність місця проживання $(-0,53)$. Прагнення самостійної реалізації себе як професіонала, професійного зростання 3 діяльністю в умовах мінімального контролю й усвідомленням ефективності своїх дій суперечать прагненню надавати допомогу суспільству в умовах конкуренції й бажанню стабільності в професійній діяльності.

Узагальнення вищенаведеного дозволило констатувати, що тільки військовослужбовці 3 ТПІ «мораторій» дають адекватну оцінку своєї самоефективності. За всіх інших ТПІ військовослужбовці схильні применшувати свою здатність до самоефективності. Незалежно від ТПІ особистості $є$ зворотній зв'язок професійних орієнтацій (когнітивний компонент) i самоефективності (поведінковий компонент професійної «Я-концепції»). Слід мати на увазі, що відповідно до ТПІ військовослужбовця є різні професійні орієнтації.

Аналіз психологічних особливостей самооцінки (емоційний компонент професійної «Я-концепції») військовослужбовців виявив, що в кожній із чотирьох груп опитаних є особистості як з неадекватною самооцінкою, схильні ії занижувати або перебільшувати, так i ті, хто адекватно оцінює себе. Адекватне розуміння й емоційне сприйняття цінності своєї особистості частіше проявляється у військовослужбовців із передчасним $(\mathrm{t}=2,3$ за $\mathrm{p} \leq 0,05)$ і дифузним $(\mathrm{t}=2,1$ за $\mathrm{p} \leq 0,01)$ TПІ, ніж у військовослужбовців з ТПІ «псевдоідентичність». Адекватна самооцінка більш характерна особистостям із дифузним ТПІ, ніж їхнім одноліткам із ТПI «мораторій». 
Характер взаємозв'язку поведінкового, когнітивного й емоційного компонентів професійної «Я-концепції» у військовослужбовців із різним ТПІ має певні відмінності.

ТПІ «передчасний». Зворотній взаємозв'язок елементів когнітивного компонента професійна компетентність $(0,79)$, автономія $(0,68)$ - стабільність роботи $(-0,52)$, служіння $(-0,54)$ та емоційного компонентна - самооцінка $(0,57)$. Професійні орієнтації бажання допомагати людям і мати стабільну роботу є бар'єром щодо професійної орієнтації прагнення індивідуального професійного зростання й самооцінки.

ТПІ «мораторій». Прямий характер взаємозв'язку когнітивного компонента стабільність роботи $(0,78)$ і емоційного компонента - самооцінка $(0,56)$. Взаємний позитивний вплив стабільності роботи, мінімальної ймовірності змін у робочій діяльності й адекватності розуміння й емоційного сприйняття себе.

ТПІ «дифузний». Зворотній взаємозв'язок когнітивного компонента - інтеграція стилів життя $(0,81)$, стабільність місця проживання $(0,69)$ і служіння $(-0,82)$ i емоційного компонента - самооцінка $(0,66)$. Несумісність одночасного поєднання в когнітивному компоненті професійної орієнтації бажання допомагати людям 3 іншими професійними орієнтаціями, такими як прагнення до стабільності, і бажання внести особистісні цінності в робочу діяльність та зі складовою поведінкового компонента самооцінка.

ТПІ «псевдоідентичність». Зворотній взаємозв'язок складових когнітивного компонента - інтеграція стилів життя $(0,80)$ і підприємництво $(-0,53)$ та емоційного компонента - самооцінка $(0,76)$. Професійна орієнтація, спрямована на розвиток креативних здібностей і бажання створення власної діяльності, суперечить як професійній орієнтації, що проявляється через уявлення про свою професію як поєднання в ній своїх життєвих принципів і особистих цінностей, так і самооцінці як ознаки емоційної складової професійної «Я-концепції».

Узагальнення вищенаведеного дозволяє констатувати, що ТПІ позначається на адекватності розуміння й емоційному сприйнятті цінності своєї особистості. Воно частіше проявляється у військовослужбовців із передчасним і дифузним ТПІ, ніж у їхніх колег 3 ТПІ «псевдоідентичність». Адекватність розуміння й емоційного сприйняття цінності своєї особистості більше притаманні військовослужбовцям із дифузним ТПІ, ніж їхнім колегам із ТПІ «мораторій».

Висновки. Підводячи підсумки, можна констатувати як подібні тенденції, так i відмінності щодо характеристик структурних елементів професійної «Я-концепції», характеру зв'язку між цими компонентами.

Когнітивний компонент (професійні орієнтації). Серед усіх можливих кар'єрних орієнтацій військовослужбовці роблять акцент на тому, що робота й місце проживання повинні бути стабільні, для них важливим $є$ відчуття власної безпеки як у професійній діяльності, так і в особистому просторі.

Поведінковий компонент (самоефективність). Складові когнітивного й поведінкового компонентів професійної «Я-концепції» перебувають у зворотному взаємозв'язку. Але слід мати на увазі, що відповідно до ТПІ військовослужбовця $є$ 
різні професійні орієнтації.

Є відсутнім зв'язок між показниками всіх трьох компонентів професійної «Яконцепції». $€$ лише зв’язок між складовими іiі когнітивного й емоційного компонентів.

ТПІ визначає певні відмінності в усіх структурних елементах професійної «Яконцепції».

Когнітивний компонент (професійні орієнтації). Серед військовослужбовців 3 ТПІ «дифузний» і «псевдоідентичність» відсутні ті, хто прагне зробити кар'єру. Самостійність у роботі та у своїх діях домінує серед військовослужбовців 3 ТПI «псевдоідентичність» порівняно з іхніми колегами 3 передчасним ТПІ. Бажання бути керівником постає мотивувальним фактором у військовослужбовців 3 ТПI «мораторій» порівняно 3 їх колегами 3 ТПІ «псевдоідентичність». Для військовослужбовців із дифузним ТПІ найбільш важливим є бажання стабільності й безпеки в роботі, ніж для військовослужбовців із ТПІ «псевдоідентичність».

Поведінковий компонент (самоефективність). Лише у військовослужбовців з ТПІ «мораторій» є адекватна оцінка своєї самоефективності. В усіх інших ТПІ чітко виражена схильність до применшення своєї здатності до самоефективності. $€$ зворотній зв'язок професійних орієнтацій (когнітивний компонент) i самоефективності (поведінковий компонент професійної «Я-концепції»). При цьому слід мати на увазі, що відповідно до ТПІ військовослужбовця $є$ різні професійні орієнтації.

Емоційний компонент (самооцінка). Адекватність розуміння й емоційне сприйняття цінності своєї особистості частіше проявляється у військовослужбовців із передчасним і дифузним ТПІ, ніж у їхніх колег з ТПІ «псевдоідентичність». Військовослужбовці 3 дифузним ТПІ більш адекватно розуміють $\mathrm{i}$ емоційно сприймають цінність своєї особистості порівняно 3 їхніми колегами 3 ТПI «мораторій».

Отже, наявність взаємозв'язку між складовими когнітивного й емоційного компонентів професійної «Я-концепції» залежно від ТПІ військовослужбовця визначається як різним характером, так і неоднорідністю цих складових.

\section{Література:}

1. Бабелюк О.В. Психологічний зміст, структура і функції професійного самовизначення військовослужбовців, що проходять військову службу за контрактом. Вісник Національної академії Державної прикордонної служби України. 2011. Вип. 5.

2. Баранік В. А. Психологічні особливості самооцінки військовослужбовців 3 девіантною та деліквентною поведінкою : дис... канд психол. Наук : 19.00.01. Київ, 2004. 221 с.

3. Джанерьян С. Т. Системный подход к изучению профессиональной «Я-концепции». Вестник Оренбургского государственного университета. 2005. № 4. С. 162-169.

4. Рикель А. М. Профессиональная Я-концепция и профессиональная идентичность в структуре самосознания личности : часть 1. Психологические исследования: электрон. науч. журн. 2011. № 2(16). URL : http://psystudy.ru. 0421100116 0017 
5. Рикель А. М. Профессиональная Я-концепция и профессиональнаая идентичность в структуре самосознания личности : часть 2. Психологические исследования : электрон. науч. журн. 2011. № 3 (17). URL : http://psystudy.ru. 0421100116\0034

6. Шнейдер Л. Б. Личностная, гендерная и профессиональная идентчность: теория и методы диагностики. М. : Изд-во Моск. психол.-соц. ин-та, 2007. С.123.

\section{References:}

1. Babeliuk, O. V. (2011), Psykholohichnyi zmist, struktkra i funktsii profesiinoho samovyznachennia viiskovosluzhbovtsiv, shcho prokhodiat viiskovu sluzhbu za kontraktom [Psychological content, structure and functions of professional self-determination of servicemen under contract military service], Visnyk Natsionalnoi akademii Derzhavnoi prykordonnoi sluzhby Ukrainy, 2011, Vol. 5.

2. Baranik, V. A. (2004), Psykholohichni osoblyvosti samootsinky viiskovosluzhbovtsiv z deviantnoiu ta delikventnoiu povedinkoiu [Psychological features of self-esteem of servicemen with deviant and delinquent behavior] : dys...kand psykhol. nauk: 19.00.01. Kyiv, $221 \mathrm{p}$.

3. Dzhaner`yan, S. T. (2005), Sistemny j podkhod k izucheniyu professional `noj «Ya-konczepczii» [A systematic approach to the study of professional "I-concept"], Vestnik Orenburgskogo gosudarstvennogo universiteta, No. 4, pp. 162-169.

4. Rikel', A. M. (2011), Professional`naya Ya-konczepcziya i professional'naya identichnost' $v$ strukture samosoznaniya lichnosti [Professional self-concept and professional identity in the structure of self-identity] : Chast`1. Psikhologicheskie issledovaniya: e`lektron. nauch. zhurn, No. 2(16), available at : http://psystudy.ru. 0421100116 0017

5. Rikel', A. M. (2011), Professional`naya Ya-konczepcziya i professional'naya identichnost` $v$ strukture samosoznaniya lichnosti [Professional self-concept and professional identity in the structure of self-identity] : Chast 2. Psikhologicheskie issledovaniya: e’lektron. nauch. zhurn. No. 3(17), available at : http://psystudy.ru. 0421100116\0034

6. Shnejder, L. B. (2007), Lichnostnaya, gendernaya i professional'naya identchnost: teoriya $i$ metody diagnostiki [Personal, gender and professional identity: theory and diagnostic methods], Izd-vo Mosk. psikhol.-socz. in-ta, Moscow, p. 123.

\section{Olena Nauchitel, Yurii Gulyi, Gennadiy Sadikov}

\section{PSYCHOLOGICAL STRUCTURE OF A PROFESSIONAL "I-CONCEPT" OF MILITARY PERSONNEL WITH DIFFERENT TYPE PROFESSIONAL IDENTITY}

The aim of the study. Identify the features of the structure of professional «Iconcepti» of military personnel in accordance with the type of their professional identity (TPI).

Research methods. Conversation method, testing.

Sample description. The study involved 100 military personnel with different TPI.

Conclusions. Summarizing, we can state both similar trends and differences in the characteristics of the structural elements of the professional «I-concept», the nature of the relationship between these components.

Cognitive component (professional orientation). Among all possible career orientations, military personnel emphasize that work and place of residence must be stable and important for them, a sense of personal safety, both in professional activity and in 
personal space.

Behavioral component (self-efficacy). The components of the cognitive and behavioral components of the professional self-concept are in feedback. But it should be borne in mind that according to the TPI of military personnel are different professional orientations.

There is no correlation between the metrics of all three components of the professional self-concept. There is only a link between the components of its cognitive and emotional components.

TPI identifies certain differences in all structural elements of the professional selfconcept.

Cognitive component (professional orientations). There are no «diffuse» and «pseudoidentity» military personnel from the TPI who are seeking a career. Autonomy at work and in its actions dominates among the military personnel with a «pseudo-identity» TPI compared to their counterparts with a premature TPI. The desire to be a leader is a motivating factor for military personnel with a TPI «moratorium» compared to their counterparts with a TPI «pseudo-identity». For military personnel with diffuse TPI, the most important is the desire for stability and safety at work, than for military personnel with TPI «pseudo-identity».

Behavioral component (self-efficacy). Only military personnel with a TPI «moratorium» have an adequate assessment of their self-efficacy. All other TPIs have a clear tendency to diminish their capacity for self-efficacy. There is a feedback of professional orientation (cognitive component) and self-efficacy (behavioral component of professional self-concept). However, it should be borne in mind that according to the TPI of military personnel are different professional orientations.

Emotional component (self-esteem). Adequacy of understanding and emotional perception of the value of one's personality is more often manifested in military personnel with premature and diffuse TPI than their counterparts with TPI «pseudo-identity». Military personnel with diffuse TPI are more aware of and emotionally perceived the value of their personality than their counterparts with the TPI «moratorium».

The presence of the relationship between the components of the cognitive and emotional component of the professional "I-concept", depending on the military personnel's TPI is determined both by the different nature and heterogeneity of these components.

Key words: professional self-concept, professional identity, personality type.

Олена Научитель, Юрій Гулий, Геннадій Садіков

\section{ПСИХОЛОГІЧНА СТРУКТУРА ПРОФЕСІЙНОӤ «Я-КОНЦЕПЦӤॠ ВІЙСЬКОВОСЛУЖБОВЦІВ ІЗ РІЗНИМ ТИПОМ ПРОФЕСІЙНОЇ ЧДЕНТИЧНОСТІ}

Мета дослідження. Виявити особливості структури професійної «Я-концепції» військовослужбовців відповідно до типу їхньої професійної ідентичності (ТПІ).

Методи дослідження. Метод бесіди, тестування.

Опис вибірки. У дослідженні взяли участь 100 військовослужбовців із різним 
TПI.

Висновки. Підводячи підсумки, можна констатувати як подібні тенденції, так i відмінності щодо характеристик структурних елементів професійної «Я-концепції», характеру зв'язку між цими компонентами.

Когнітивний компонент (професійні орієнтації). Серед усіх можливих кар'єрних орієнтацій військовослужбовці роблять акцент на тому, що робота й місце проживання повинні бути стабільними, для них важливим є відчуття власної безпеки як у професійній діяльності, так і в особистому просторі.

Поведінковий компонент (самоефективність). Складові когнітивного й поведінкового компонентів професійної «Я-концепції» перебувають у зворотному взаємозв'язку. Але слід мати на увазі, що відповідно до ТПІ військовослужбовця $\epsilon$ різні професійні орієнтації.

Відсутній зв’язок між показниками всіх трьох компонентів професійної «Яконцепції». Є лише зв'язок між складовими іiі когнітивного й емоційного компонентів.

ТПІ визначає певні відмінності в усіх структурних елементах професійної «Яконцепції».

Когнітивний компонент (професійні орієнтації). Серед військовослужбовців із ТПІ «дифузний» і «псевдоідентичність» відсутні ті, хто прагне зробити кар'єру. Самостійність у роботі й у своїх діях домінує серед військовослужбовців із ТПI «псевдоідентичність» порівняно з їхніми колегами 3 передчасним ТПІ. Бажання бути керівником постає мотивувальним фактором у військовослужбовців із ТПI «мораторій» порівняно 3 їхніми колегами 3 ТПІ «псевдоідентичність». Для військовослужбовців із дифузним ТПІ найбільш важливим є бажання стабільності й безпеки в роботі, ніж для військовослужбовців із ТПІ «псевдоідентичність».

Поведінковий компонент (самоефективність). Лише у військовослужбовців із ТПІ «мораторій»є адекватна оцінка своєї самоефективності. В усіх інших ТПІ чітко виражена схильність до применшення своєї здатності до самоефективності. $€$ зворотній зв'язок професійних орієнтацій (когнітивний компонент) i самоефективності (поведінковий компонент професійної «Я-концепції»). При цьому слід мати на увазі, що відповідно до ТПІ військовослужбовця $є$ різні професійні орієнтації.

Емоційний компонент (самооцінка). Адекватність розуміння й емоційне сприйняття цінності своєї особистості частіше проявляється у військовослужбовців із передчасним і дифузним ТПІ, ніж у їхніх колег 3 ТПІ «псевдоідентичність». Військовослужбовці 3 дифузним ТПІ більш адекватно розуміють і емоційно сприймають цінність своєї особистості порівняно 3 їхніми колегами 3 ТПІ «мораторій».

Наявність взаємозв'язку між складовими когнітивного й емоційного компонентів професійної «Я-концепції» залежно від ТПІ військовослужбовця визначається як різним характером, так і неоднорідністю цих складових.

Ключові слова: професійна «Я-концепція», професійна ідентичність, тип особистості. 
Nauchitel Olena - Ph.D. in Psychology, Associate Professor, Associate Professor of the Department of Psychology Faculty of Humanities of the National Aerospace University «Kharkiv Aviation Institute».

Научитель Олена - кандидат психологічних наук, доцент, доцент кафедри психології гуманітарного факультету Національного аерокосмічного університету ім. М. Є. Жуковського «Харківський авіаційний інститут».

e-mail: elena.nauchitel@gmail.com, https://orcid.org/0000-0002-4069-4858

Gulyi Yurii - Ph.D in Psychology, Associate Professor, Associate Professor of the Department of Psychology Faculty of Humanities of the National Aerospace University «Kharkiv Aviation Institute».

Гулий Юрій - кандидат психологічних наук, доцент, доцент кафедри психології гуманітарного факультету Національного аерокосмічного університету ім. М. Є. Жуковського «Харківський авіаційний інститут».

e-mail: gyip@ukr.net,https://orcid.org/0000-0001-6035-8811

Sadikov Gennadiy - Doctor of Biology Sciences, Professor, Professor of the

Department of Psychology Faculty of Humanities of the National Aerospace University «Kharkiv Aviation Institute».

Садіков Геннадій - доктор біологічних наук, професор кафедри психології гуманітарного факультету Національного аерокосмічного університету ім. М. Є. Жуковського «Харківський авіаційний інститут».

e-mail: sadicov707@gmail.com

Надійшла до редакції 29.10.2019. Розглянута на редколегії 19.11.2019.

\section{Рецензенти:}

Доктор філософських наук, професор, головний науковий співробітник відділу гуманітарної політики Національного інституту стратегічних досліджень при Президентові України Степіко М. Т.

Кандидат психологічних наук, доцент, завідувач кафедри психології гуманітарного факультету Національного аерокосмічного університету ім. М. Є. Жуковського «XАI» Жидко М. Є. 